\title{
Hadis Keutamaan Penuntut Ilmu: \\ Analisis Parsial dan Simultan Riwayat Abu Darda' dalam Sunan Abu Dawud
}

\begin{abstract}
(Hadith on the Virtue of Knowledge Seeker: Partial and Simultaneous Analysis of Abu Darda' History in Sunan Abu Dawud)
\end{abstract}

\author{
Nur Abdul Kholik Nugroho ${ }^{1}$, Damanhuri ${ }^{2}$ \\ ${ }^{1}$ Institut Islam Studies Muhammadiyah Pacitan ${ }^{2}$ UIN Sunan Ampel Surabaya, Indonesia \\ 1kholiknugroho123@gmail.com, ${ }^{2}$ damanhurilimatiga@gmail.com
}

DOI: $10.29240 /$ alquds.v5i2.2535

Submitted: 2021-02-24 | Revised: 2021-08-04 | Accepted: 2021-09-03

\begin{abstract}
The purpose of this study was to conduct a partial and simultaneous analysis of the exposure of hadith regarding the virtues of studying. The scope of this research is the main hadith narrated by Abu Darda' and take it out by Imam Abu Dawud. Data related to the hadith and the quality of the narrators were collected using the documentation method. Data analysis using content analysis method. Based on the partial analysis, it was found that this hadith is of authentic quality, because (1) all the narrators have the degree of tsiqah. (2) this hadith is muttasil. (3) this hadith does not contain syaz, because there is no contradiction with the naqli propositions of both the Qur'an and the hadith which have a higher quality sanad. (4) this hadith does not contain 'illat, because there is no conflict with the aqli argument either with common sense, senses or science. Based on simultaneous analysis; This hadith has 4 tabi'. However, because the quality of the hadith is authentic, the existence of this tabi' hadith has no effect on improving its quality. As for the syabid, it turns out that there are 2 syahids, this means that the hadith was narrated through two friends, namely Abu Darda 'and Abu Hurairah.
\end{abstract}

Keywords: partial analysis; simultaneous analysis; the virtues of knowledge seeker

Abstrak. Tujuan penelitian ini adalah melakukan analisis parsial dan simultan terhadap paparan hadis mengenai keutamaan menuntut ilmu. Ruang lingkup penelitian ini adalah hadis utama riwayat Abu Darda' dan ditakhrij oleh Imam Abu Dawud. Data yang berkaitan dengan hadis dan kualitas perawinya dihimpun menggunakan metode dokumentasi. Analisis data menggunakan metode content analysis. Berdasarkan analisis parsial ditemukan bahwa hadis ini berkualitas shabih lidzatih, karena (1) semua periwayat berderajat tsiqah. (2) sanad hadis ini muttasil. (3) matan hadis ini tidak mengandung syar, karena tidak ditemukan adanya kontradiksi dengan dalil naqli baik Al-Qur'an dan hadis yang kualitas sanadnya lebih tinggi. (4) matan hadis ini tidak mengandung “illat, karena 
tidak ditemukan adanya pertentangan dengan dalil aqli baik dengan akal sehat, indera maupun ilmu pengetahuan. Berdasarkan analisis simultan; hadis ini mempunya 4 tabi. Akan tetapi karena dari sisi kualitas hadis tersebut sudah berkualitas shahih, maka keberadaan dari hadis tabi'nya ini tidak berpengaruh dalam meningkatkan kualitasnya. Adapun mengenai syahidnya, ternyata ditemukan adanya 2 hadis syahid, ini artinya hadis tersebut diriwayatkan melalui dua sahabat yaitu Abu Darda' dan Abu Hurairah.

Kata kunci: analisis parsial; analisis simultan; keutamaan penuntut ilmu

\section{Pendahuluan}

Syuhudi Ismail menilai ada empat hal yang memotivasi Ulama Mubadisin untuk melakukan penelitian atau pengkajian hadis secara mendalam, yaitu: (1) Hadis adalah sumber hukum Islam kedua setelah Al-Qur'an, (2) Tidak semua hadis dicatat pada zaman Nabi Muhammad SAW, (3) Munculnya pemalsuan Hadis yang di lakukan oleh kaum Syi'ah, Yahudi dan lain-lain (4) proses pembukuan atau kodifikasi hadis terhambat. ${ }^{1}$

Syuhudi Ismail mengemukakan empat alasan yang masuk akal untuk mendorong melakukan filterisasi atau penyaringan hadis pembukuan hadis dalam buku-buku hadis yang muktabar. Beberapa alasan yang mendorong untuk melakukan pengkajian atau pemeriksaan ulang hadis ini adalah:

1. Kitab atau buku-buku hadis tidak semuanya mengandung unsur hadis yang lengkap termasuk di dalamnya ada matan, sanad dan mukharrij-nya. Meski banyak Buku Hadis, yang berisi Hadis lengkap beserta unsur-unsurnya tetapi banyak juga kita temukan kitab hadis yang isinya hanyalah matan atau sanad saja, ada juga yang berisi hanya matan dan mukharrij-nya saja tidak ada sanadnya. Hadis yang berada di dalam kitab seperti ini tentu saja tidak bisa di teliti derajat keshahihannya karena unsurnya tidak lengkap.

2. Sebagian besar hadis yang terdapat dalam kitab atau buku-buku hadis baru di kaji pada sanadnya saja atau hanya di ketahui seberapa valid perawinya saja, adapun tentang ketersambungan (muttasid) sanad belum di teliti atau di kaji secara mendalam. Terkadang kualitas atau derajat isi (matan) hadis belum dianalisis atau dipelajari.

3. Semua hadis yang ada di buku hadis hanya diperiksa sebagian atau satu sanad, dan masih jarang melakukan pengkajian sanad secara keseluruhan atau simultan. Kesimpulan penelitian tentang hadis jalur satu sanad saja hasilnya berbeda dengan kesimpulan studi hadis melalui banyak jalur sanad atau simultan.

4. Setelah melakukan pengkajian atau penelitian hadist dan memperoleh hasil kualitas yang valid atau shahih, selanjutnya kita amalkan dalam kehidupan sehari-hari. Ketika kita mau mengamalkan hadis kita harus mengetahui terlebih

\footnotetext{
${ }^{1}$ Syuhudi Ismail, Pengantar Ilmu Hadits, (Bandung: Angkasa, 1994), hal. 75-76
} 
dahulu bagaimana figh al hadis atau pemahaman yang benar dari hadis tersebut. Untuk memahami isi suatu hadis tidak cukup kalau kita hanya melihat dari satu jalur sanad saja untuk itu kita harus mengumpulkan hadis-hadis yang memiliki tema yang sama sehingga kita bisa mendapatkan pemahaman yang komprehensif dari matan hadis tersebut.

Berdasarkan argumen tersebut di atas, riset hadis secara simultan ialah metode atau sesuatu kebutuhan yang tidak bisa di tawar lagi untuk mengetahui mutu atau kualitas hadist. Dari segi isi kandungannya, hadis Nabi saw terdapat beberapa kategori, diantaranya: hadist abkam, hadist akblaq serta badist tarbawi.

Analisis simultan adalah suatu proses analisis suatu hadis dengan menelusuri dan mencari hadis tabi' atau mutabi'nya maupun hadis shabidnya. Oleh karena itu, analisis simultan memerlukan pembahasan tentang: hadis tabi' dan hadis shabid. ${ }^{2}$

Dengan demikian akan dapat diketahui releven atau tidak relevannya unsur-unsur yang terdapat dalam kaidah tersebut bagi tujuan penelitian sanad hadis. Maka kaidah tersebut ditelaah secara kritis dalam penelitian sanad hadis secara simultan.

Adapun penelitian sebelumnya yang relevan dengan yang di teliti oleh penulis adalah Pertama, seperti yang di lakukan oleh Ahmad Fauzi dan Alfiah. Mereka meneliti kajian hadis urgensi dan keutamaan kedudukan ilmu yang bermanfaat sebagai asset akhirat menggunakan pendekatan takhrij.

Hadis utama yang diteliti oleh Ahmad Fauzi dan Alfiah adalah hadis yang diriwayatkan oleh Abu Hurairah, dan ditakhrij oleh Imam Muslim. Dalam hadis tersebut, perawi ada 5: Yahya bin Yahya, Abu Muawiyah, Al-A'mas, Abu Sholih, Abu Hurairah. Hadis Ahmad Fauzi dan Alfiah teliti juga tidak terdapat Syawabid, atau jalur Sahabat yang lain keculai Abu Hurairah. Sedangkan Hadis yang penulis teliti berbeda dengan mereka yaitu hadis riwayat Abu Darda'dan di takhrij oleh Abu Dawud. Dalam hadis yang penulis teliti perawinya ada 6: Musaddad bin Musarhad, Abdullah bin Daud, Ashim bin Roja' bin Haiwat, Daud bin Jamil, Katsir bin Qais, Abu Darda'. Kemudian hadis yang penulis teliti juga memiliki jalur sahabat yang lain selain Abu Darda' yaitu melalui jalur sahabat Abu Hurairah.

2 Damanhuri, Hadits-Hadits Al Fitrah dalam Penelitian Simultan, (Sidoarjo: Dwiputra Pustaka Jaya, 2016). 
Berdasarkan data di atas dapat di ketahui kebaruan dari hadis yang penulis teliti berbeda dengan hadis yang di teliti oleh Ahmad Fauzi dan Alfiah. ${ }^{3}$

Kedua, penelitian terdahulu yang relevan dengan penelitian yang di lakukan penulis adalah penelitian yang di lakukan oleh Abdul Karim Amrullah, judul penelitian beliau adalah keutaman ilmu dan Adab dalam perspektif Islam. Perbedaan penelitian Abdul Karim Amrullah dengan penelitian penulis adalah, penelitian Abdul Karim Amrullah bermaksud mencari dalil-dalil baik dalam Al Qur'an maupun hadis tentang keutamaan Ilmu dan Adab. Jadi bagaimana Islam memandang pentingnya Ilmu dan adab itu. Sedangkan penelitian dari penulis adalah bermaksud untuk melakukan analisis parsial atau jalur satu sahabat dan simultan atau jalur lebih dari satu sahabat dari hadis keutamaan menuntut Ilmu yang di riwayatkan oleh Abu Darda' dan di tahkrij oleh Abu Dawud. Guna mengetahui keshahihan hadis tersebut baik dari sisi sanad maupun matan hadis, sehingga terlihat novelty (kebaruan) penelitian yang penulis lakukan sangat berbeda dengan penelitian yang di lakukan oleh Abdul Karim Amrullah. ${ }^{4}$

Ketiga, penelitian yang di lakukan oleh Mera Fidiana dengan judul Pendidikan Islam Menurut Az-Zarnuji (Studi Analisis Konsep Ilmu dan Keutamannya dalam Kitab Ta'lim Muta'alim). Metode yang di gunakan oleh Mera Fidiana dalam penelitiannya adalah metode analisis hermeneutic dan metode analisis deskriptif. Temuan dari penelitian Mera Fidiana adalah Pendidikan yang di tekankan oleh Az Zarnuji dapat di kelompokkan menjadi tiga yaitu Pertama, akhlak kepada Allah SWT, guru dan murid dalam proses pembelajaran di niatkan kepada Allah SWT, kedua akhlak murid terhadap gurunya dan ketiga akhlak kepada ilmu itu sendiri. Sedangkan penelitian dari penulis adalah bermaksud untuk melakukan analisis parsial atau jalur satu sahabat dan simultan atau jalur lebih dari satu sahabat dari hadis keutamaan menuntut Ilmu yang di riwayatkan oleh Abu Darda' dan di tahkrij oleh Abu Dawud. Guna mengetahui keshahihan hadis tersebut baik dari sisi sanad maupun matan hadis, sehingga terlihat novelty (kebaruan) penelitian yang penulis lakukan sangat berbeda dengan penelitian yang di lakukan oleh Mera Fidiana. ${ }^{5}$

Keempat, penelitian selanjutnya di lakukan oleh Muzakkir dengan judul penelitian, Keutamaan belajar dan mengajarkan Al Qur'an (Metode Maudhu'i

\footnotetext{
${ }^{3}$ Ahmad Fauzi dan Alfiah, Urgensi dan Keutamaan Kedudukan Imu yang Bermanfaat sebagai Asset Akbirat, Journal of Education and Teaching, Vol. 2 No. 2, http://ejournal.uinsuska.ac.id/index.php/JETE 2021

${ }^{4}$ Abdul Karim Amrullah, Keutamaan Ilmu dan Adab Dalam Perspektif Islam, At-Ta'lim Jurnal Kajian Pendidikan Agama Islam, Vol 2 Edisi 1, http://www.ejournal.annadwah.ac.id/index.php/Attalim/article/view/133, 2020

${ }^{5}$ Mera Fidiana, Pendidikan Islam Menurut Az-Zarnuji (Studi Analisis Konsep Ilmu dan Keutamannya dalam Kitab Ta'lim Muta'alim), Skripsi: Pendidikan Agama Islam, IAIN metro, 2018. https:/ / repository.metrouniv.ac.id/id/ eprint/2382/
} 
dalam perspektif Hadis). Hadis utama yang di teliti oleh beliau adalah hadis Khoirukum man ta'allamal quraana wa'allamahu (HR Bukhori). Adapun metode yang di gunakan adalah metode maudhu'i dengan jalan mengidentifikasi semua hadis tetang keutamaan belajar dan mengajarkan Al Qur'an sebagai tema sentral penelitian ini. Dengan melalui lafaz-lafaz hadis yang berkaitan dengan pendidikan baik dalam bentuk fi'il, isim kemudian melakukan analisis kontekstual. Sedangkan penelitian dari penulis adalah bermaksud untuk melakukan analisis parsial atau jalur satu sahabat dan simultan atau jalur lebih dari satu sahabat dari hadis keutamaan menuntut Ilmu yang di riwayatkan oleh Abu Darda' dan di tahkrij oleh Abu Dawud. Guna mengetahui keshahihan hadis tersebut baik dari sisi sanad maupun matan hadis, sehingga terlihat novelty (kebaruan) penelitian yang penulis lakukan sangat berbeda dengan penelitian yang di lakukan oleh Muzakkir. ${ }^{6}$

Kelima, penelitian yang di lakukan oleh Agus Setiawan dengan judul Reorientasi Keutamaan Ilmu dalam Pendidikan Perspektif Al Ghazali pada Kitab Ihya 'Ulumuddin. Penelitian yang dilakukan oleh Agus setiawan ini adalah berusaha menggali secara mendalam keutamaan Ilmu dalam pendidikan di tinjau dari sudut pandang Hujjatul Islam Imam Al Ghazali terutama dalam Kitab Ihya 'Ulumuddin, jadi penelitian ini merupakan library research (penelitian kepustakaan). Menurut Al Ghazali Manusia yang memiliki ilmu dapat memperoleh derajat atau kedudukan paling terhormat di antara sekian banyak makhluk di permukaan bumi dan langit karena ilmu dan amalnya. Sedangkan penelitian dari penulis adalah bermaksud untuk melakukan analisis parsial atau jalur satu sahabat dan simultan atau jalur lebih dari satu sahabat dari hadis keutamaan menuntut Ilmu yang di riwayatkan oleh Abu Darda' dan di tahkrij oleh Abu Dawud. Guna mengetahui keshahihan hadis tersebut baik dari sisi sanad maupun matan hadis, sehingga terlihat novelty (kebaruan) penelitian yang penulis lakukan sangat berbeda dengan penelitian yang di lakukan oleh Agus Setiawan.

Penelitian ini merupakan library research atau penelitian kepustakaan. Dalam uapaya pengumpulan data terkait matan hadis, sanad, biografi dari perawi hadis, menggunakan metode pengumpulan data dokumentasi, dengan cara menelusuri kembali ke kitab-kitab hadist muktabar dan melihat biografi para perawi. Data dan pengamatan sanad hadis diperoleh dari kitab hadis standar yang menyebutkan sanad hadis secara lengkap. Adapun kitab hadis tersebut antara lain:

\footnotetext{
${ }^{6}$ Muzakkir, Keutamaan belajar dan mengajarkan Al Qur'an (Metode Maudbu'I dalam perspektif Hadits). Jurnal Lentera Pendidikan, Vol. 18 No. 1 http: http://journal.uinalauddin.ac.id/index.php/lentera_pendidikan/article/view/684/672 tahun 2015

${ }^{7}$ Agus Setiawan, Reorientasi Keutamaan Ilmu dalam Pendidikan Perspektif Al Ghazali pada Kitab Ibya Ulumuddin, Jurnal Al Qalam, Vol. 12 No.1 https://jurnal.stiqamuntai.ac.id/index.php/al-qalam/article/view/18/18 tahun 2018.
} 
Shahih al-Bukhari, Sahih Muslim, Sunan Al Kubro Al Baihaqi, Sunan Abu Dawud, Musnad Al Bazar, Musnad Imam Ahmad Ibnu Hanbal.

Data tentang biografi para perawi hadis diantaranya; Nama lengkap dari perawi, Tahun wafat perawi, siapa saja gurunya, siapa saja muridnya, komentar para pakar atau Ulama Mubadisin berkaitan validitas atau kualitas kedhabitan dan keadilan perawi yang di peroleh dari kitab biografi perawi hadis. Kitab-kitab tersebut antara lain; Tahdhib al-Kamal, Tabdhib al-Tahdbib Li al-Dhahabi, Taqrib alTabdhib, Kbulasah Tadhbib Tahdbib al-Kamal, Syiar A'lam An Nubala Li Adz Drababi, Al Mughni fi Ad Dhuafa' Li Adz Dhababi, Syadzarat Ad Dzabab fi Akhbar Man Drabab Li Ibnul Imad al Hanbali, Mukbtasor Al Kamil fi Ad Dhuafa' Li Taqiyudin Abmad bin Ali, Al Kasyîf Fî Ma'rifati Man Labû Riwãyah Fî Al Kutub Al Sittah Li Adz Drababi, At Tsiqat li Ibnu Hiban, Tarikh Dimasqy Li Ibnu Asakir, Tadzkirah Al Hufadz Li Adz Dhababi, Ma'rifatu Tsiqah Li Abmad bin Abdillah Abul Hasan al Ijliy, Mashahir Ulama al Amsar Li Muhammad Ibn Hiban, al-Ishabah fi Tamyiz ashShahabah Li Ibnu Hajar al Asqalani, Ghunyah al Multamis Idhob al Multabis Li Abu Bakar Abmad bin Ali.

Sedangkan untuk analisis data yang telah diperoleh digunakan content analysis atau analisis isi yaitu: suatu teknik penelitian penalaran dengan mengidentifikasi karakteristik khusus dalam teks secara sistematis dan obyektif (Klaus Krippendorff, 1991, hal. 19). ${ }^{8}$ Dengan cara ini, peneliti terlebih dahulu menentukan syarat validitas (keshahihan) hadis yaitu ada 4 syarat. Empat syarat keshahihan hadist tersebut yakni: 1) Semua perawi adalah tsiqah (adil dan kuat hafalannya atau dhabit), 2) Sanad atau transmitternya bersambung, 3) Tidak adanya unsur shadh, 4) Tidak mengandung illat. Jika empat syarat-syarat ini terpenuhi semua maka kualitas dari hadis yag di teliti bisa shahih atau bisa hasan. Akan tetapi jika dari keempat syarat tersebut ada yang belum terpenuhi maka kulitas hadis tersebut bisa dhaif atau bahkan maudhu'.

\section{Pembahasan}

\section{Lafadz Hadis ${ }^{9}$}

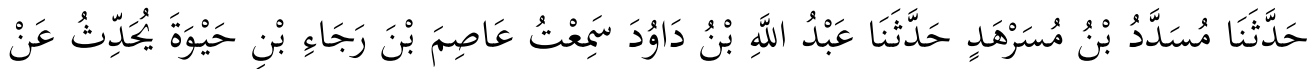

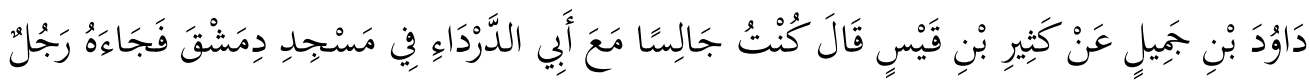

\footnotetext{
1991) hal. 19

${ }^{8}$ Klaus Krippendorff, , Analisis Isi, Pengantar, Teori dan Metodologi. (Jakarta: Rajawali Press,

9 Abu Dawud Sulaiman bin Al Ash'ath, Sunan Abu Dawnd, Juz. 10, hal. 49, No. 3157, CD Shoftware Maktabah Syamilah, Isdar al Thani
} 


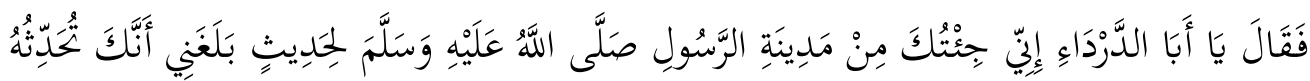

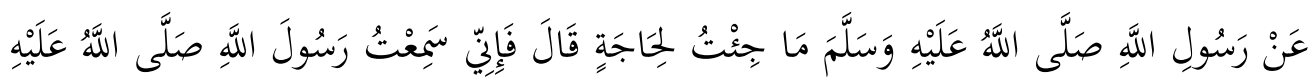

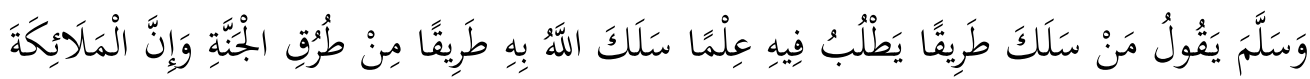

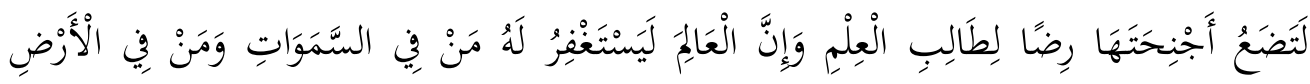

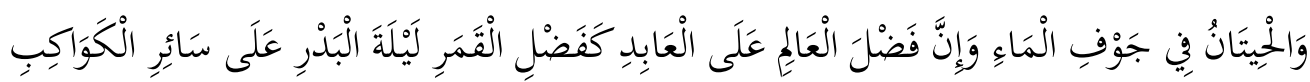

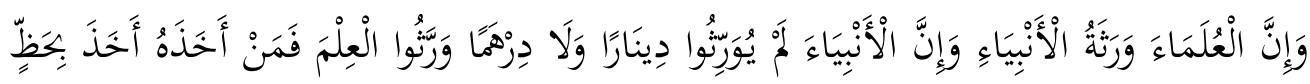

\section{Biografi Perawi}

1. Musaddad bin Musarhad

Nama Lengkapnya adalah Musaddad bin Musrahad bin Musrabil Abul Hasan Al Bashori. Beliau berada pada thabaqot ke-10, wafat pada tahun $228 \mathrm{H}$. Guru-Guru beliau dalam meriwayatkan hadis adalah: 'Ibad bin 'Ibad Al Mahlabi, Abdullah bin Dawud Al Khoribi, Abdullah bin Yahya bin Abi Katsir, Abdul Aziz bin Abdul Shomad, Abdul Aziz bin Mukhtar. Adapun Murid-murid beliau dalam periwayatan hadis: Al Bukhari, Abu Dawud, Ibrahim bin Ya'qub, Ahmad bin Abdullah bin Shalih, Ismail bin Ishaq Al Qadhi. Penilaian Ulama terhadapnya: Ibnu Hibban Mengatakan Tsiqah ${ }^{10}$, Ibnu Qani menagatakan Tsiqah, Ibnu Adi juga mengatakan Musaddad bin Musarhad adalah seorang musnid pertama di Basroh. ${ }^{11}$ Ibnu hajar mengatakan tsiqah, hafidz. ${ }^{12}$

2. Abdullah bin Dawud

Nama lengkapnya adalah Abdullah bin Dawud bin Amir Al Mahdani AsSya'bi. Beliau berada pada thabaqat ke 9, Lahir tahun $126 \mathrm{H}$ dan meninggal tahun 213 H. Guru-guru beliau dalam meriwayatkan hadis: Sulaiman Al A'mas, Syarik bin Abdullah An-Nakho'I, Tholhah bin Yahya bin Tholhah bin Ubaidillah, Ashim bin Raja', Afiyah bin Yazid Al Qadhi. Adapun murid-murid beliau dalam meriwayatkan hadis: Muhammad bin Yahya bin Abdul Karim, Muhammad bin

Thani

${ }^{10} \mathrm{Al}$ Mizzi, Tahdzibul Kamal, Juz 26, hal. 376 CD Shoftware Maktabah Syamilah, Isdar al al Thani

${ }^{11}$ Ibnu hajar, Tabdhibu Tabdhib, Juz 10 hal 99 CD Shoftware Maktabah Syamilah, Isdar ${ }^{12}$ Ibnu Hajar, Taqribu Tahdhib, Juz 1 hal 935, CD Shoftware Maktabah Syamilah, Isdar al Thani 
yazid, Muhammad bin Yunus, Musaddad bin Musrahad, Nasr bin Ali. Penilaian Ulama terhadapnya: Muawiyah bin Sholih mengatakan tsiqah, shoduq ${ }^{13}$, Abul Hatim mengatakan tsiqah, Ibnu Sa'ad juga mengatakan tsiqah, 'abid ${ }^{14}$, Ibnu Hajar mengatakan tsiqah, 'abid. ${ }^{15}$

3. 'Ashim bin Roja' bin Haiwat

Nama lengkapnya adalah 'Ashim bin Roja' bin Haiwat Al Kindi Al Falestini. Beliau berada pada thabaqat ke 8. Guru-guru beliau dalam meriwayatkan hadis adalah: Dawud bin Jamil, Rabi'ah bin Yazid, Roja' bin Haiwat, Urwah bin Ruaim, Al Qaim Abi Abdurrahman. Adapun murid-murid beliau dalam meriwayatkan hadis: Sulaiman bin Ziyad, Abdullah bin Dawud Al Khoribi, Abdullah bin Yazid, Usman bin Faid, Ali bin Qasim Al Kindi. Penilaian Ulama terhadapnya: Ibnu Hibban mengatakan tsiqah ${ }^{16}$, Abu Zur'ah mengatakan Laa ba'tsa Bih, Ibnu Hibban juga mengatakan tsiqah ${ }^{17}$, Ibnu Hajar mengatakan Shoduq ${ }^{18}$, Abu Zur'ah mengatakan orangnya Laa ba'tsa Bih. ${ }^{19}$

4. Dawud bin Jamil

Nama lengkapnya adalah Dawud bin Jamil. Beliau berada pada thabaqat ke-7. Guru-guru beliau dalam meriwayatkan hadis adalah: Katsir bin Qais, Katsir bin Murrah, Qais bin Katsir. Adapun murid-murid beliau dalam meriwayatkan hadis diantaranya: Ashim bin Roja' bin Haiwat. Penilaian Ulama terhadapnya: Ibnu Hibban mengatakan orangnya $t s i q a h^{20}$, Daruqutni mengatakan Dawud bin Jamil orangnya Majbul, Al-Azdi juga mengatakan Dhoif, Majbul. ${ }^{21}$ Ibnu hajar

Thani

13 Al Mizzi, Tahdzibul Kamal, Juz 14, hal. 458 CD Shoftware Maktabah Syamilah, Isdar al

${ }^{14}$ Shofiyudin Ahmad bin Abdillah, Khulasob Tabdhibu Tabdhib Al Kamal fi Asma' Ar Rijal Juz 1 hal 196, CD Shoftware Maktabah Syamilah, Isdar al Thani

Thani

${ }^{15}$ Ibnu Hajar, Taqribu Tahdhib, Juz 1 hal 503, CD Shoftware Maktabah Syamilah, Isdar al

16 Al Mizzi, Tabdribul Kamal, Juz 13, hal. 483, CD Shoftware Maktabah Syamilah, Isdar al Thani

${ }^{17}$ Ibnu hajar, Tahdhibu Tahdhib, Juz 5 hal 37, CD Shoftware Maktabah Syamilah, Isdar al Thani

${ }^{18}$ Ibnu Hajar, Taqribu Tahdhib, Juz 1 hal 471, CD Shoftware Maktabah Syamilah, Isdar al Thani

${ }^{19}$ Shofiyudin Ahmad bin Abdillah, Khulasob Tabdbibu Tabdhib Al Kamal fi Asma' Ar Rijal Juz 1 hal 182, CD Shoftware Maktabah Syamilah, Isdar al Thani

${ }^{20}$ Al Mizzi, Tahdzibul Kamal, Juz 8, hal. 378, CD Shoftware Maktabah Syamilah, Isdar al Thani al Thani

${ }^{21}$ Ibnu hajar, Tahdhibu Tahdhib, Juz 3 hal 181, CD Shoftware Maktabah Syamilah, Isdar 
mengatakan dhoif ${ }^{22}$, Ibnu Hibban mengatakan Dawud bin Jamil orangnya Tsiqah $^{23}$

\section{Katsir bin Qais}

Nama lengkapnya adalah Katsir, bin Qois As Syami. Beliau berada pada thabaqat ke-3. Guru beliau dalam meriwayatkan hadis di antaranya adalah Abu Darda'. Adapun murid beliau dalam meriwayatkan hadis diantaranya adalah Dawud bin Jamil. Penilaian Ulama terhadapnya: Ibnu Hibban mengatakan Katsir bin Qois orangnya Tsiqah ${ }^{24}$, Ibnu Hajar mengatakan dhoif ${ }^{25}$, Daruqutni mengatakan Katsir bin Qois orangnya dhoif ${ }^{6}$, Shofiyudin Ahmad bin Abdillah mengatakan Katsir bin Qois isnadnya mudhthorib ${ }^{27}$.

6. Abu Darda'

Nama lengkapnya adalah Uwaimir bin Zaid Ibnu Qois Al Anshori, Abu Darda' Al Khozroji. Beliau berada pada thabaqat ke-1 atau Sahabat dari Rasulullah SAW. Beliau wafat pada tahun $32 \mathrm{H}$. Diantara Guru-guru beliau adalah: Nabi Muhammad SAW, Zaid bin Tsabit, Aisyah Ummul Mukminin. Adapun muridmurid beliau diantaranya: Qabishah bin Dhu'yab, Qais bin Abi Hazim, Katsir bin Qais, Katsir bin Murrah. Penilaian Ulama terhadapnya: Rasulullah SAW bersabda Hakim umatku adalah Uwaimir bin Zaid atau Abu Darda'. ${ }^{28}$ Ibnu Abdil Bar mengatakan Abu Darda orangnya Ashoha 'inda Ahlil Hadis (Orang yang paling terpercaya dalam ahli hadis ${ }^{29}$, Ibnu Hajar mengatakan Abu Darda' orangnya

\footnotetext{
al Thani

22 Ibnu Hajar, Taqribu Tabdhib, Juz 1 hal 305, CD Shoftware Maktabah Syamilah, Isdar

${ }^{23}$ Shofiyudin Ahmad bin Abdillah, Khulasob Tabdhibu Tabdhib Al Kamal fi Asma' Ar Rijal Juz 1 hal 109, CD Shoftware Maktabah Syamilah, Isdar al Thani

${ }^{24}$ Al Mizzi, Tahdzibul Kamal, Juz 24 hal. 149, CD Shoftware Maktabah Syamilah, Isdar al Thani al Thani

${ }^{25}$ Ibnu Hajar, Taqribu Tabdbib, Juz 1 hal 809, CD Shoftware Maktabah Syamilah, Isdar

${ }^{26}$ Syamsudin Abu Abdillah, Mizanul I'tidal, Juz 3 hal. 409, CD Shoftware Maktabah Syamilah, Isdar al Thani

${ }^{27}$ Shofiyudin Ahmad bin Abdillah, Khulasoh Tabdhibu Tabdhib Al Kamal fi Asma' Ar Rijal Juz 1 hal 320, CD Shoftware Maktabah Syamilah, Isdar al Thani

${ }^{28}$ Al Mizzi, Tabdzibul Kamal, Juz 22 hal. 470, CD Shoftware Maktabah Syamilah, Isdar al Thani

${ }^{29}$ Ibnu hajar, Tahdbibu Tahdhib, Juz 8 hal 176, CD Shoftware Maktabah Syamilah, Isdar al Thani
} 
'Abid atau Ahli Ibadah ${ }^{30}$, Ibnu Mu'in mengatakan Abu Darda' orangnya Laisa bi Syai' dan Imam An-Nasa'i Mengatakan Laisa bibi Ba'as ${ }^{31}$.

\section{Menguji Persambungan Sanad}

Jika kita tinjau secara empiris, untuk menguji ketersambungan sanad yaitu dengan melaukan kajian mendalam atau analisis terhadap redaksi periwayatan yang di pakai perawi ketika meriwayatkan hadisnya.

Hasil dari penyajian sekaligus analisis mendalam data ketersambungan sanad dari hadis yang penulis teliti dapat dipaparkan:

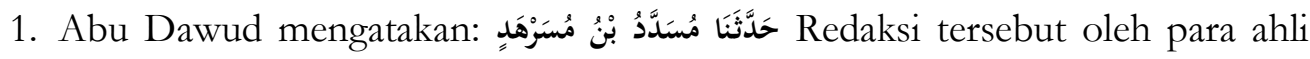
hadis (mubadditsin) digunakan dalam periwayatan hadis dalam bentuk al-sima' min lafdri al-shaykh ${ }^{32}$ (لسماع عن لفظ الثيخ). Menurut makna, As Sima' artinya guru membaca isi dari hafalan atau tulisan, dan muridnya dapat mendengarkan saja atau mencatat sambil menyimak gurunya. Oleh karena itu, ini berarti adanya pertemuan antara Imam Abu Dawud dan gurunya (Musadad bin Musrahad), sehingga sanad antara Imam Abu Dawud dan Musadad bin Musrahad bersambung (muttasi).

2. Musadad bin Musrahad berkata: حَدََّنَّا عَبْدُ اللَّهِ بْنُ دَاؤدَ Redaksi tersebut oleh para ahli hadis (mubadditsin) digunakan dalam periwayatan hadis dalam bentuk alsima' min lafdri al-shaykh33 (السماع من لفظ الثيخ). Menurut makna, As Sima' artinya guru membaca isi dari hafalan atau tulisan, dan muridnya dapat mendengarkan saja atau mencatat sambil menyimak gurunya. Oleh karena itu, ini berarti adanya pertemuan antara Musadad bin Musrahad dan gurunya (Abdullah bin Dawud), sehingga sanad antara Musadad bin Musrahad dan Abdullah bin Dawud bersambung (muttasi).

3. Abdullah bin Dawud mengatakan: سَمْعْتُ عَاصِمَ بْنَ رَجَاءِ بْنِ حَيْوَة Redaksi tersebut oleh para ahli hadis (mubadditsin) digunakan dalam periwayatan hadis dalam bentuk al-sima' min lafdzi al-shaykhb3 (السماع من لفظ الشيخ). Menurut makna, As Sima' artinya guru membaca isi dari hafalan atau tulisan, dan muridnya dapat mendengarkan saja atau mencatat sambil menyimak gurunya. Oleh karena itu, ini berarti adanya pertemuan antara Abdullah bin Dawud dan gurunya (Ashim

\footnotetext{
${ }^{30}$ Ibnu Hajar, Taqribu Tabdhib, Juz 1 hal 759, CD Shoftware Maktabah Syamilah, Isdar al Thani

${ }^{31}$ Shofiyudin Ahmad bin Abdillah, Khulasoh Tabdhibu Tabdhib Al Kamal fi Asma' Ar Rijal Juz 1 hal 298, CD Shoftware Maktabah Syamilah, Isdar al Thani

${ }^{32}$ Mahmud Tahhan, tt, Taysir Mustalah al-Hadith, (Kuwait: Maktabah al Maa'rif li al-nasr wa al-tawzii) ,Juz 1, hal. 85, CD Shoftware Maktabah Shamilah, Isdar al-Thani.

${ }^{33}$ Mahmud Tahhan, tt, Taysir Mustalah al-Hadith,,hal. 85

${ }^{34}$ Mahmud Tahhan, tt, Taysir Mustalah al-Hadith,,hal. 85
} 
bin Roja'), sehingga sanad antara Abdullah bin Dawud dan Ashim bin Roja' bersambung (muttasil).

4. Ashim bin Roja' mengatakan: يُحَدِّثُ عَنْ دَاؤدَ بْنِ بَمَيلٍ Redaksi tersebut oleh para ahli hadis (mubadditsin) digunakan dalam periwayatan hadis dalam bentuk al-sima' min lafdzi al-shaykhb35 (السماع من لفظ الثيخ). Menurut makna, as sima' artinya guru membaca isi dari hafalan atau tulisan, dan muridnya dapat mendengarkan saja atau mencatat sambil menyimak gurunya. Oleh karena itu, ini berarti adanya pertemuan antara Ashim bin Roja' dan gurunya (Dawud bin Jamil), sehingga sanad antara Ashim bin Roja' dan Dawud bin Jamil bersambung (muttasi).

5. Dawud bin Jamil mengatakan: عَنْ كَثِير بْنِ قَيِْ Penuturan dari riwayat Dawud bin Jamil memiliki redaksi 'an (عَ) tetapi 'an' anah bukan berarti otomatis sanad terputus. Bahkan bisa dikatakan sanadnya bersambung (muttasil) karena: (a) Dawud bin Jamil merupakan seorang perawi yang tsigah, (b) Dawud bin Jamil bukanlah perawi yang mudallis, (c) Dawud bin Jamil dimungkinkan pernah atau telah bertemu dengannya guru beliau yaitu Katsir bin Qais.

6. Katsir bin Qais mengatakan: كُنْتُ جَالِسنا مَعَ أَبِي الدَّرْدَاءَ Redaksi tersebut oleh para ahli hadis (mubadditsin) digunakan dalam periwayatan hadis dalam bentuk alsima' min lafdri al-shaykhb' (السماع من لفظ الثنيخ). Menurut makna, As Sima' artinya guru membaca isi dari hafalan atau tulisan, dan muridnya dapat mendengarkan saja atau mencatat sambil menyimak gurunya. Oleh karena itu, ini berarti adanya pertemuan antara Katsir bin Qais dan gurunya (Abu Darda'), sehingga sanad antara Katsir bin Qais dan Abu Darda' bersambung (muttasi).

\section{Kesimpulan Sanad}

Setelah disajikan analisa data-data yang berhubungan dengan ketbiqoban para periwayat yang ada dalam sanad hadis yang diteliti, dan data-data persambungan sanadnya, maka disimpulkan sebagai berikut:

1. Semua periwayat yang ada dalam sanad hadis yang berjumlah: 6 periwayat, seluruhnya berkualitas: tsiqah.

2. Semua periwayat masing-masing bertemu dengan periwayat yang berstatus sebagai gurunya, dengan demikian sanadnya muttasil.

3. Dengan demikian, dapat disimpulkan bahwa hadis yang diteliti sanadnya berkualitas: sabih al-isnad.

\footnotetext{
${ }^{35}$ Mahmud Tahhan, tt, Taysir Mustalah al-Hadith,,,hal. 89
}

${ }^{36}$ Mahmud Tahhan, tt, Taysir Mustalah al-Hadith,„,hal. 85 


\section{Penelitian Untuk Matan Hadis}

\section{Menguji Shadh Tidaknya Matan Hadis}

Jika dilakukan peninjauan secara empiris, untuk menguji shadh atau tidaknya matan dari suatu hadis, dengan cara mengkonfirmasi apakah hadis yang diteliti sesuai atau sejalan dengan Al Qur'an atau hadis yang lain yang memiliki tema sama dengan kualitas dari segi sanadnya lebih tinggi; 1) Katakanlab; "Apakah sama mereka orang-orang yang mengetabui dengan mereka orang-orang yang tidak mengetabui?" [Qs. Az Zumar: 9], 2) "Dia (Allab) mengajarkan manusia tentang apa yng belum di ketabui manusia" [Qs. Al Alaq: 5], 3) "Dan di atas tiap-tiap orang yang memiliki pengetabuan (ilmu) ada Allab yang Maha Mengetabui" [Qs. Yusuf: 76], 4) "Dan diantara kalian ada yang di kembalikan ke usia yang paling lemah atau pikun, agar dia (manusia) tidak mengetahui sesuatu apapun yang pernah dia ketabui sebelumnya." [Qs. An Nahl: 70]

Ayat di atas secara jelas mengimplikasikan bahwa mencari ilmu adalah tugas dan tanggung jawab kita sebagai manusia dan hamba-Nya yang setia. Karena Allah sebagai pemilik ilmu akan memberikan hadiah atau balasan yang berlipat ganda yang bagi mereka yang serius dalam menuntut ilmu. Selain itu, salah satu prasyarat untuk mencari ilmu adalah keikhlasan atau kerelaan hati, karena motivasi mencari ilmu bukan hanya untuk memuaskan hajat duniawi yang sementara. Karena banyak orang saat ini mencari ilmu untuk mendapatkan gengsi, gengsi mereka akan meningkat di mata masyarakat kalau mereka memiliki ilmu.

Biasanya orang seperti itu juga sombong secara intelektual, dan dia tidak menyadari bahwa pengetahuannya sebenarnya membuatnya bodoh. Karena ilmu yang dimilikinya justru menjauhkannya dari kesadaran akan keberadaannya sebagai hamba Tuhan. Intinya, semakin tinggi pengetahuan seseorang, semakin harus ia meningkatkan kemandiriannya pada hakikat batin kehidupan manusia, sehingga memiliki keyakinan yang kuat kepada Sang Pencipta. Oleh karena itu, sebenarnya proses mencari ilmu adalah proses pendakian, dalam proses ini diperlukan mujahadah dan keikhlasan, seperti proyeksi keimanan. Semakin kita mengerti atau semakin banyak yang kita ketahui, semakin kita menyadari betapa bodoh dan lemahnya kita di hadapan Allah. Ketika kita bisa mengetahui kebenaran hakiki, itulah puncak kebahagiaan kita sebagai hamba Allah SWT, karena seperti yang dibicarakan Hadis, inilah "surga" yang sejati.

Hadis utama yang di riwaytakan oleh Abu Hurairah di atas memiliki dua makna yaitu makna internal dan eksternal. Secara internal, hadis ini menjadi doktrin bahwa tujuan akhir kehidupan di dunia ini akan menjadi ahli surga setelah fase kematian kelak. Dengan sesorang menuntut ilmu maka akan membuatanya mudah untuk meraih surga. Tentunya inilah ilmu agama yang wajib di ketahui oleh setiap muslim dan muslimah. Secara eksternal, hadis di atas dapat dipahami sebagai salah satu prasyarat untuk mencapai kebahagiaan atau surganya dunia 
adalah ilmu. Proposisi eksternal semacam ini secara umum dapat dipahami sebagai kebijaksanaan (wisdom).

Kembali kepada hadis riwayat Abu Darda' dan di takhrij oleh Abu Dawud ia berkata bahwa Rasulullah shallallahu 'alaibi wa sallam bersabda,

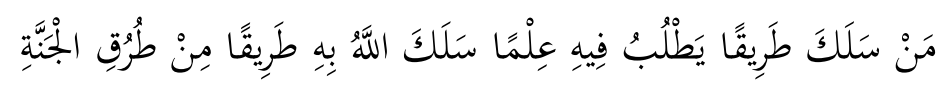

Barang siapa yang menempuh jalan untuk. mencari ilmu, maka Allah akan menjadikan untuknya jalan dari jalan-jalan ke Surga. (HR. Abu Dawnd)

Penjelasan tentang Allah akan memberi kemudahan jalan dari jalan-jalan surga memiliki 4 makna seperti yang di sebutkan oleh Ibnu Rajab Al-Hanbali:

Pertama: Dengan mengikuti jalan mencari ilmu, Allah akan memudahkannya masuk surga. Kedua: Pengetahuan dibutuhkan karena seseorang mendapat bimbingan atau hidayah. Hidayah inilah yang membawa seseorang ke surga. Ketiga: Dengan menuntut ilmu akan mengarah pada produksi pengetahuan atau ilmu yang lain dan dengan ilmu itu akan mengantarkan orang untuk masuk surga. Sebagaimana firman Allah SWT: "Dan Allah SWT akan memberikan tambahan petunjuk. kepada mereka atau orang-orang yang sudah mendapatkan petunjuk." (Qs. Maryam ayat 76), dan firman Allah SWT di ayat yanng lain; "Dan bagi orangorang yang mau menerima petunjuk, maka Allah akan menambabkan petunjuk kepada mereka dan memberikan balasan berupa taqwa (Qs. Muhammad ayat 17). Keempat: Dengan ilmu, Allah beri kemudahan perjalanan seseorang menuju surga yaitu saat melewati shirath. Bahkan Ibnu Rajab al Hambali memberi kesimpulan, menuntut ilmu adalah jalan paling ringkas untuk menuju surga Allah SWT. ${ }^{37}$

\section{Menguji Mu'allal (cacat) Tidaknya Matan Hadis}

Jika kita identifikasi secara empiris, untuk menguji apakah matan hadis itu ada mu'allal atau tidak dengan cara yang menyandingkan atau membandingkan makna matan hadis yang diteliti dengan dalil 'aqli, apakah bertentangan atau tidak? Kalau bertentangan dengan akal, indera, dan sejarah. Maka hadisnya berarti tidak shahih, begitu pula sebaliknya.

Untuk dapat memahami cita-cita moral dari Hadis tersebut di atas, langkah pertama yang harus dilakukan adalah mengakar dalam makna Hadis. Ada dua kata kunci dalam hadis, yaitu "jalan belajar dalam menuntut ilmu" dan "jalan menuju surga". Dari perspektif sekuler, latar ilmiah di sini menghujat,

${ }^{37}$ Ibnu Rajab Al Hanbali, Jami' Al Ulum wa Al Hikam, (Beirut: Muassasah ArRisalah, 1432 H.) Juz 2, hal. 297-298. 
bertentangan dengan istilah "surga", yang merupakan bidang eskatologis dan metafisik. Kedua konteks ini disandingkan dalam arti "jalan" (thariqah), dan dari perspektif sekuler, keduanya adalah jalan atau proses. Namun, kedua jalur (proses) pada dasarnya memiliki diameter yang berlawanan. Sekaligus, dalam tafsir literal, sunnah bisa dimasukkan ke dalam hikmah universal, yakni kata "surga" bisa diturunkan menjadi makna kebahagiaan (kebahagiaan), dan untuk mewujudkannya harus melalui proses.

Surga yang diberikan kepada hamba oleh Allah tidak bisa menggantikan ibadahnya, karena nikmat surga yang abadi tidak sebanding dengan ibadah seorang hamba ketika di dunia. Karena itu, Allah mencurahkan rahmatnya. Oleh karena itu, hadis tidak perlu dipahami sebagai perkataan bahwa manusia tidak membutuhkan amal kebaikan, karena dengan melakukan amal kebaikan justru merupakan cara untuk memperoleh rahmat Allah SWT. Dan juga menajdi penentuan derajat orang di surga.

Kabar baiknya adalah bahwa jalan menuju surga sangat mudah bagi orang yang berpengetahuan atau memiliki ilmu. Mengapa demikian? Misalnya, dua orang bepergian dari tempat yang sama, tujuan yang sama, dan waktu yang sama, tetapi bisa jadi mereka akan tiba di tempat tujuan pada waktu yang berbeda. Orang pertama yang sampai di tempat tujuan lebih dulu, karena sebelum berangkat, dia sudah belajar bagaimana menghindari kemacetan jalan raya. Orang kedua hanya melaju di sepanjang jalan raya tanpa mengetahui jalan lain, sehingga dia terjebak dalam kemacetan lalu lintas.

Begitu pula dengan orang yang berilmu. Dibandingkan dengan hamba lainnya, Allah mempermudah dia untuk masuk surga. Itu karena dia belajar untuk membuat dirinya sadar akan amalan yang Allah cintai dan bisa lakukan, dan mengetahui amalan yang dibenci Allah sehingga dia bisa ditinggalkan. Bagi yang tidak mau menuntut ilmu, tidak mengerti semua ilmu, sehingga ia hanya akan melakukan amal biasa atau bahkan melakukan perbuatan yang akan mendatangkan murka Allah karena ketidaktahuananya akan ilmu tadi.

\section{Penyimpulan Uji Matan}

Setelah penulis melakukan analisis yang mendalam pada isi (matan) hadis yang diriwayatkan oleh Abu Hurairah dan di takhrij oleh Imam Al-Bukhari, dapat penulis simpulkan sebagai berikut:

1) Tidak ada shadh di dalam matan hadis tersebut, karena tidak ada kontardiksi (pertentangan) dengan ayat Al-Qur'an maupun hadis yang memiliki tema sama dengan derajat kualitas sanad lebih tinggi.

2) Tidak adanya illat pada matan hadis tersebut karena memang tidak di temukan adanya pertentangan dengan aql' baik dengan, sejarah, akal sehat, indera bahkan tidak bertentangan dengan science. Oleh sebab itu dapat kita tarik kesimpulan bahwa kualitas hadis tersebut sahih al-matani. 


\section{Kesimpulan Penelitian Hadis Secara Parsial}

Setelah penulis menyajikan dan menganalisis data-data yang berkaitan dengan tsiqah tidaknya perawi yang berada dalam sanad hadis, data yang berkaitan dengan ketersambungan sanad sekaligus matan hadis yang di riwayatkan oleh Abu Darda dan di takhrij oleh Imam Abu Dawud, maka penulis dapat menyimpulkan sebagai berikut:

a. Seluruh perawi dalam sanad hadis yang totalnya ada 6 orang perawi, semuanya memiliki kualitas tsiqah.

b. Seluruh perawi bertemu dengan perawi lain yang statusnya adalah guru mereka, oleh karena itu sanadnya bersambung (muttasil).

c. Tidak adanya shadh pada hadis tersebut karena tidak adanya pertentangan (kontradiksi) dengan $\mathrm{Al}$ Qur'an dan juga hadis yang dari segi kualitas sanadnya lebih tinggi (dalil naqh).

d. Tidak adanya illat pada matan hadis tersebut karena tidak adanya pertentangan dengan akal sehat, sejarah, indera maupun ilmu pengetahuan (dalil aqli).

Dengan demikian dapat disimpulkan bahwa hadis yang diriwayatkan oleh Abu Darda dan di takhrij Abu Dawud analisis sanadnya memperoleh sabih al-Isnad dan analisis matannya diperoleh sabih al-matan. Maka kesimpulan analisis parsialnya adalah: sabih al-badis.

\section{Analisis simultan hadis tentang keutamaan orang yang menuntut ilmu.}

\section{Paparan Jalur Sanad Lain Satu Sahabat}

Hadis tentang keutamaan orang yang menuntut ilmu riwayat Abu Darda' mempunyai 4 hadis tabi' yaitu sebagai berikut:

a. Hadis utama yang ditakhrij oleh Abu Dawud ${ }^{38}$

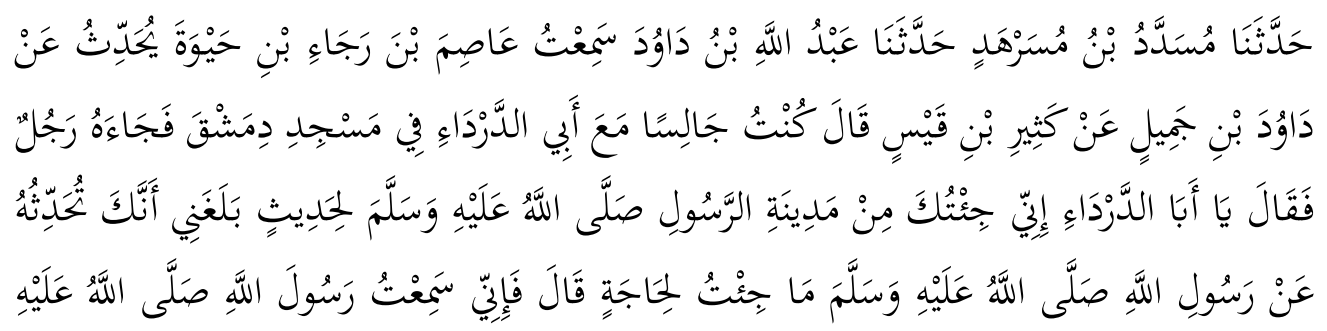

38 Abu Dawud Sulaiman bin Al Ash'ath, Sunan Abu Dawud, Juz. 10, hal. 49, No. 3157, CD Shoftware Maktabah Syamilah, Isdar al Thani 


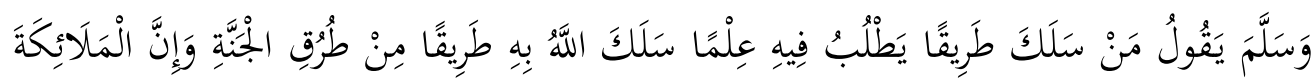

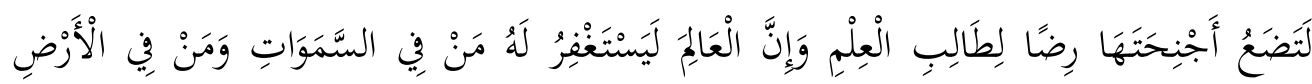

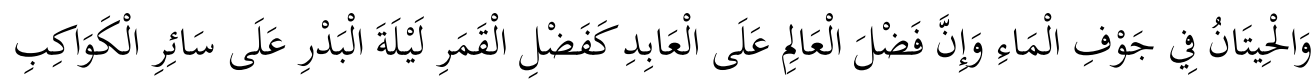

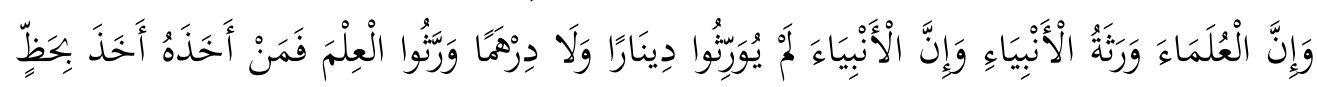

وَافِرٍ

b. Hadis yang ditakhrij oleh Ibnu Hibban ${ }^{39}$

أخبرنا محمد بن إسحاق الثقفي قال حدثنا عبد الأعلى بن حماد قال حدثنا عبد الله بن داود

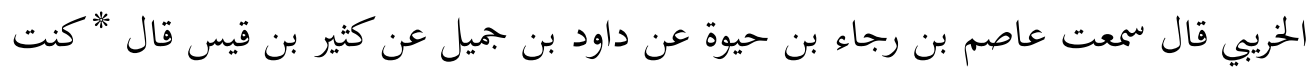

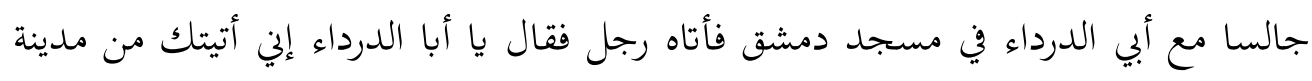

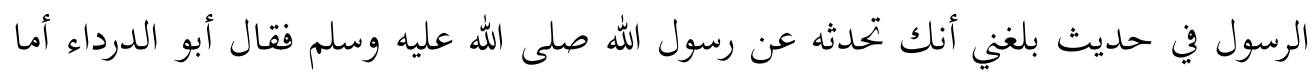

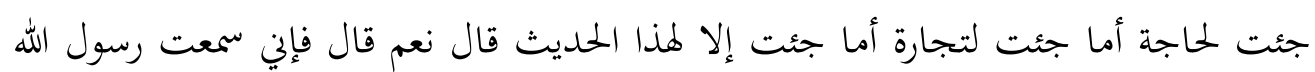

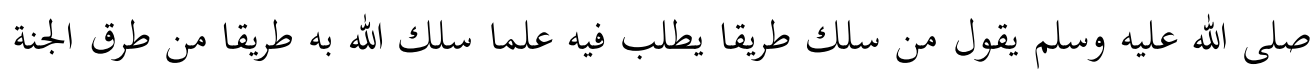

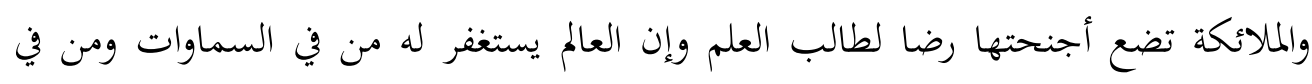

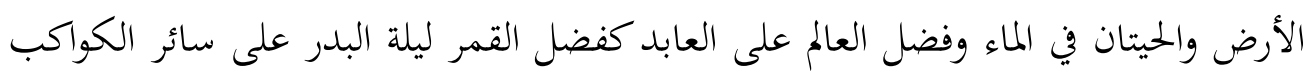

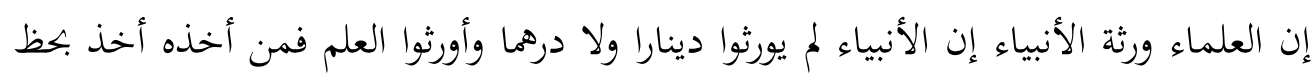

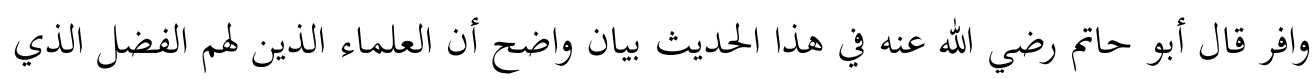

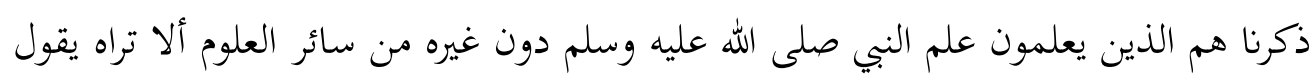

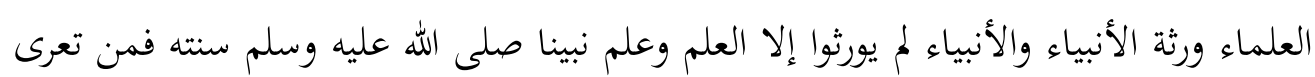
عن معرفتها لم يكن من ورثة الأنبياء 88

${ }^{39}$ Muhammad bin Hibban, Shabih Ibnu Hiban, Juz. 1, hal. 289, No. 88, CD Shoftware Maktabah Syamilah, Isdar al Thani 
c. Hadis yang ditakhrij oleh Ibnu Majah ${ }^{40}$

حدثنا نصر بن علي الجهضمي ثنا عبد الله بن داود عن عاصم بن رجاء بن حيوة عن داود بن جميل عن كثير بن قيس قال *كنت جالسا عند أبي الدرداء في مسجد دمشق فأتاه رجل فقال يا أبا الدرداء أتيتك من المدينة مدينة رسول الله صلى الله عليه وسلم لحديث بلغني أنك تحدث

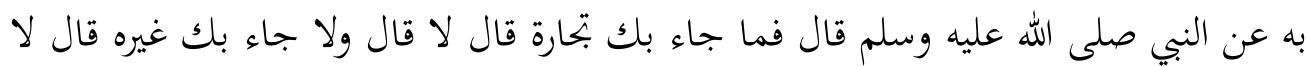
قال فإني سمعت رسول الله صلى الله عليه وسلم يقول من سلك طريقا يلتمس فيه علما سهل

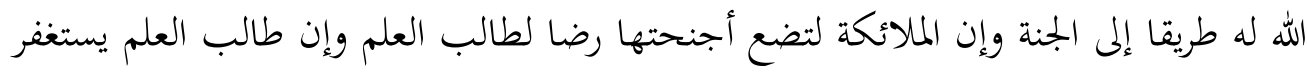

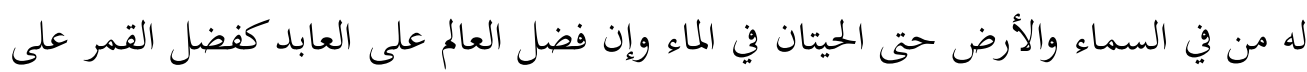
سائر الكواكب إن العلماء ورثة الأنبياء إن الأنبياء لم يورثوا دينارا ولا درهما إنما ورثوا العلم فمن

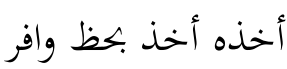

d. Hadis yang ditakhrij oleh Ad Darimi ${ }^{41}$

أخبرنا نصر بن علي ثنا عبد الله بن داود عن عاصم بن رجاء بن حيوة عن داود بن جميل عن كثير بن قيس قال * كنت جالسا مع أبي الدرداء في مسجد دمشق فاتاه رجل فقال يا أبا

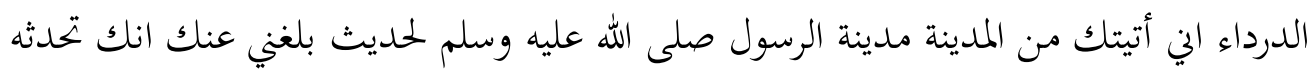
عن رسول الله صلى الله عليه وسلم قال فما جاء بك بتحارة قال لا قال ولا بغاء لك غيره قال لا قال سمعت رسول الله صلى الله عليه وسلم يقول من سلك طريقا يلتمس به علما سهل الله به طريقا من طرق الجنة فإن الملائكة لتضع أجنحتها رضا لطالب العلم وان طالب في العلم ليستغفر له من في السماء والأرض حتى الحيتان في الماء وان فضل العالم على العابد كفضل

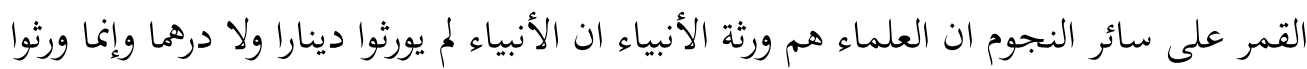

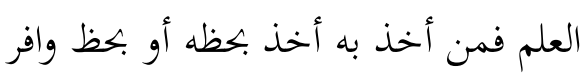

40 Abu Abdillah Muhammad Ibn Yazid, Sunan Ibnu Majah, Juz. 1, hal. 81, No. 223 CD Shoftware Maktabah Syamilah, Isdar al Thani

${ }^{41}$ Abdullah bin Abdirrahman Abu Muhammad Ad Darimi, Sunan Ad Darimi, Juz 1, hal. 110, No. 342 


\section{Bagan Seluruh alur Sanad Lain dalam Satu Sahabat:}

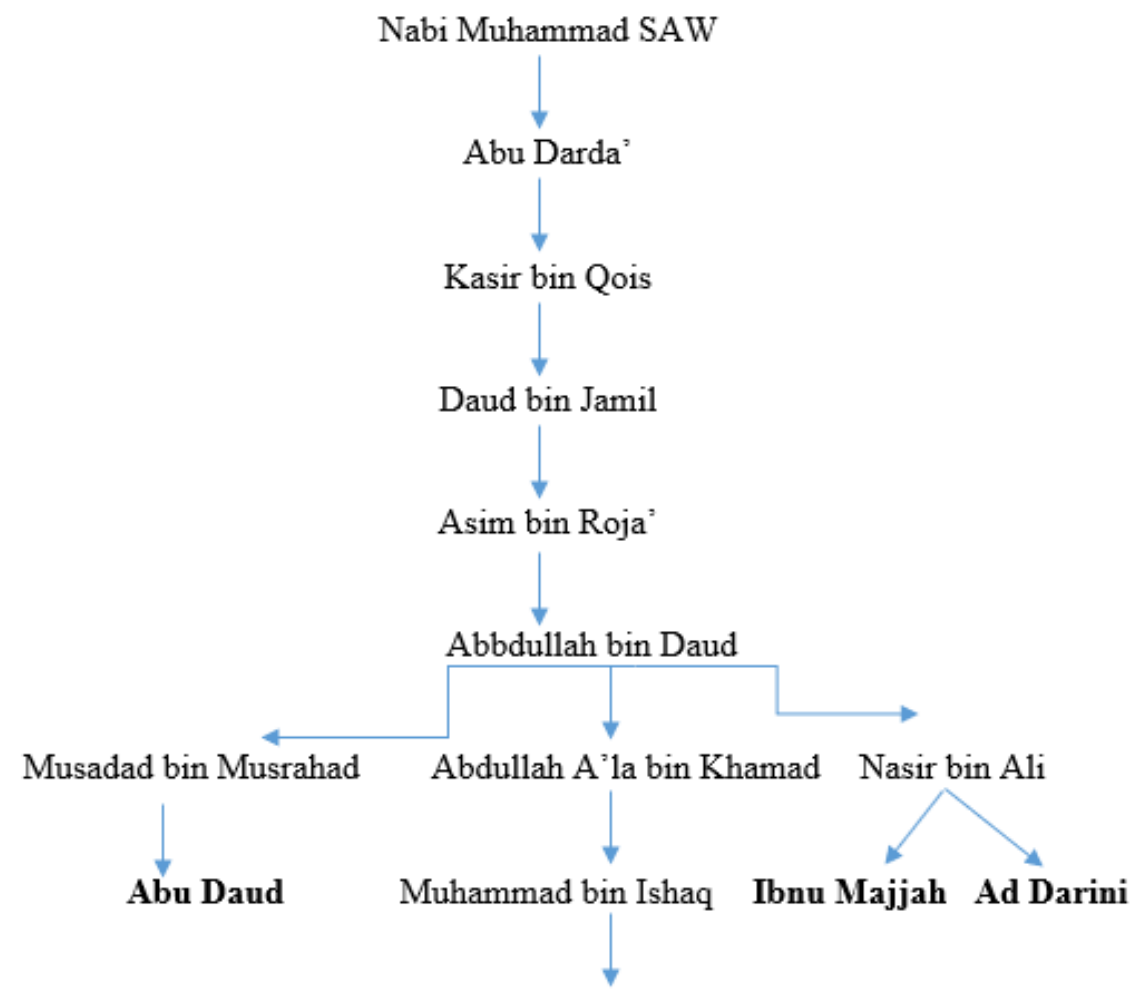

\section{Ibnu Hibban}

\section{Analisis}

Ditinjau dari segi sanadnya, hadis riwayat Abu Darda' yang ditakhrij oleh Abu Dawud, mempunyai tabi' qasir sebanyak 4 hadis: pada periwayat yang bernama: Abu Dawud (hadis utama), Ibnu Hibban, Ibnu Majah dan ad Darimi.

Tidak ada periwayat yang mendampingi Kasir bin Qois sebagai murid Abu Darda', Kasir bin Qois periwayat yang berkualitas tsiqah, maka tanpa kehadiran periwayat pendampingnya, maka kualitas hadis mutaba'nya sudah berkualitas sahih.

Begitu juga, redaksi periwayatan yang digunakan semua periwayat tersebut menggunakan redaksi 'an (عن). Karena Abu Darda' dalam riwayat hadis keutamaan orang yang menuntut ilmu menggunakan redaksi anna dengan 'anannanya yang muttashil, maka satu periwayat tersebut redaksinya muttashil, tetapi tidak bisa mengangkat menjadi muttashil al-sanad, karena sudah muttashil.

Satu periwayat Dawud bin Jamil sebagai muridnya Kasir bin Qois. Karena Dawud bin Jamil adalah periwayat yang tsiqah, maka kehadiran satu periwayat pendampingnya tidak bisa mengangkat dan meningkatkan kualitas hadis mutaba'nya yang sudah berkualitas sahih. 
Satu periwayat Asim bin Roja' sebagai muridnya Dawud bin Jamil. Karena Asim bin Roja' adalah periwayat yang tsiqah, maka kehadiran satu periwayat pendampingnya tidak bisa mengangkat dan meningkatkan kualitas hadis mutaba'nya yang sudah berkualitas sabih.

Dua periwayat yang seangkatan dengan Muhammad bin Musarhad, yakni Abdullah A'la bin Khamad dan Nasir bin Ali. Karena Muhammad bin Musarhad berkualitas tsigah dan redaksi periwayatannya menggunakan: Akbbaranaa yang berstatus muttashil, maka keberadaan dari periwayat lain tidak bisa mengangkat kualitas hadis mutaba'nya, karena sudah berstatus shabih.

Dua periwayat yang seangkatan dengan Abu Dawud, dua periwayat dari guru yang sama, yaitu: Abdul A'la bin Khamad dan Nasir bin Ali. Karena Abdullah bin Musarhad berkualitas tsigah dan redaksi periwayatannya menggunakan: Hadasana yang berstatus muttashil, maka keberadaan dari periwayat lain tidak bisa mengangkat kualitas hadis mutaba'nya, karena sudah berstatus shabih.

Jadi, keempat hadis tabi'nya tidak bisa meningkatkan kualitas hadis mutaba'nya, yaitu: hadis keutamaan orang yang menuntut ilmu yang diriwayatkan oleh Abu Darda' yang ditakhrij oleh Abu Dawud. Dengan demikian berarti bahwa hadis tabi'nya tidak berpengaruh pada peningkatan kualitas hadis mutaba'nya, yaitu: sabih lidzaatih.

\section{Paparan Jalur Sanad lain Multi Sahabat}

Selain riwayat jalur Abu Darda', hadist tentang pentingnya ilmu pengetahuan ini, juga diriwayatkan melalui jalur sahabat lain, yaitu sahabat Abu Hurairah. Hadis tersebut dengan seluruh jalurnya adalah sebagai berikut:

a. Hadis utama yang ditakhrij oleh Abu Dawud

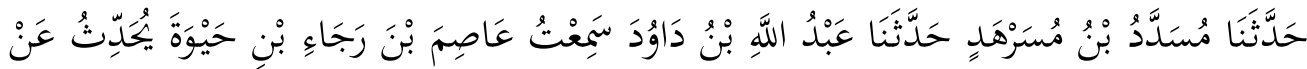

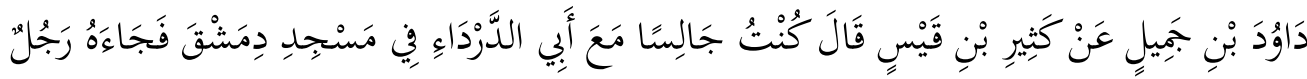

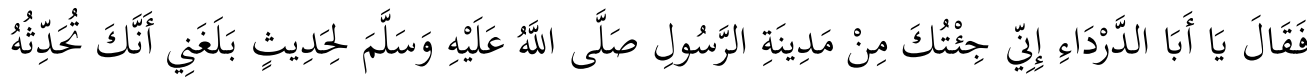

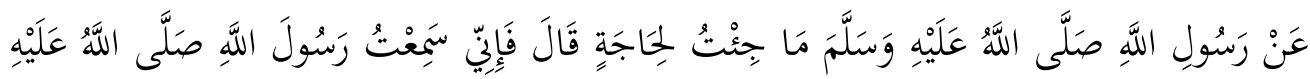

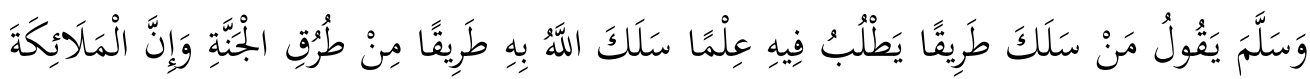

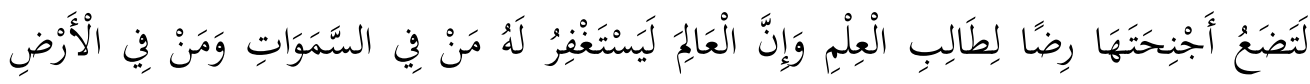

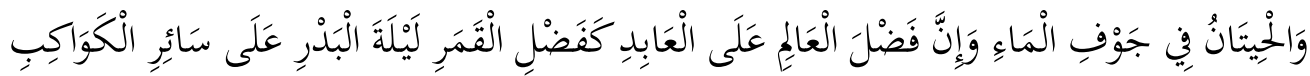




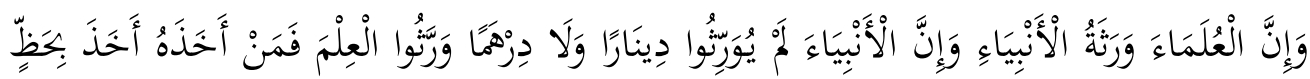

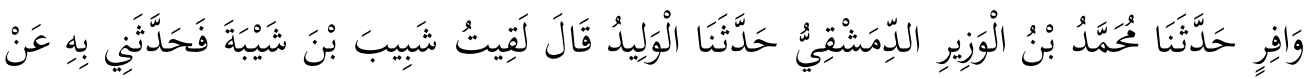

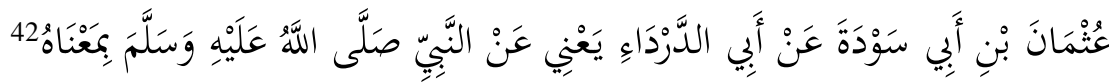

b. Hadis yang ditakhrij oleh Abu Dawud

حدثنا أحمد بن يونس ثنا زائدة عن الأعمش عن أبي صالح عن أبي هريرة قال قال رسول الله

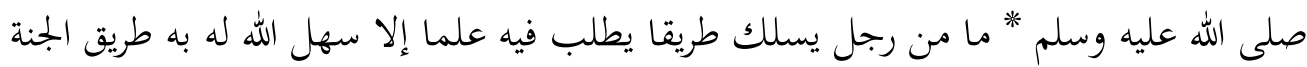

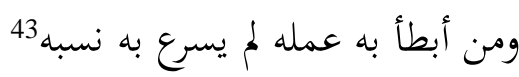

c. Hadis yang ditakhrij oleh Ad Darimi

أخبرنا أحمد بن عبد الله بن يونس ثنا زائدة عن الأعمش عن أبي صالح عن أبي هريرة قال قال

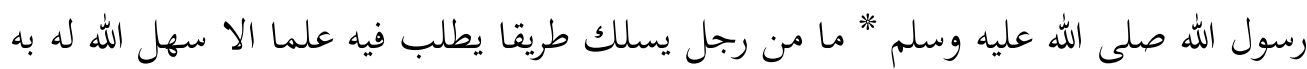
طريقا إلى الجنة ومن أبطأ به عمله لم يسرع به نسبه.

d. Hadis yang ditakhrij oleh Ibnu Majah ${ }^{45}$

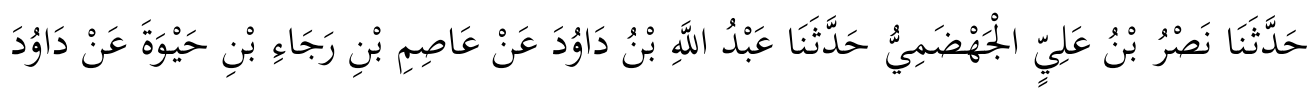

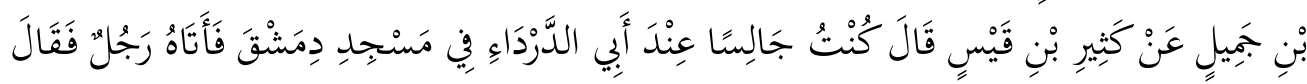

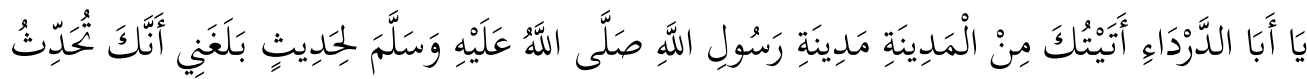

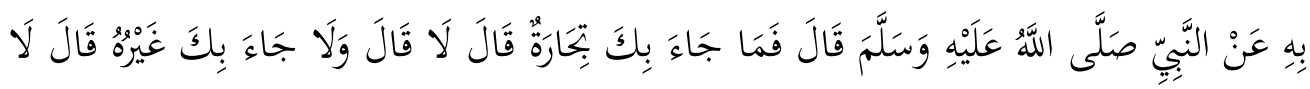

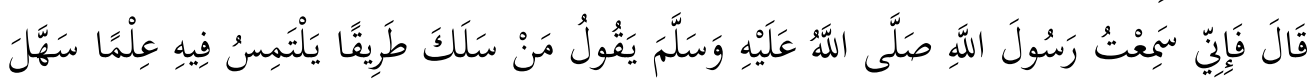

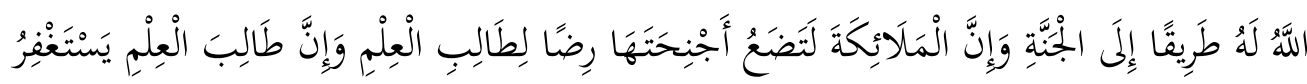

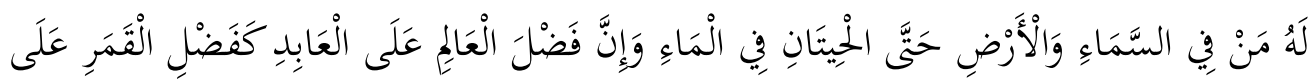

42 Abu Dawud Sulaiman bin Al Ash'ath,Sunan Abu Dawud Juz. 10, hal. 49, No. 3157, CD Shoftware Maktabah Syamilah, Isdar al Thani

${ }^{43}$ Abu Dawud Sulaiman bin Al Ash'ath, Juz. 3, hal. 318, No. 3643, CD Shoftware Maktabah Syamilah, Isdar al Thani

${ }_{44}$ Abdullah bin Abdirrahman Abu Muhammad Ad Darimi, Sunan Ad Darimi, Vol. 1, hal. 111, No. 344, CD Shoftware Maktabah Syamilah, Isdar al Thani

45 Abu Abdillah Muhammad ibn Yazid, Sunan Ibnu Majah, Juz. 1, hal. 259, No. 219, CD Shoftware Maktabah Syamilah, Isdar al Thani 


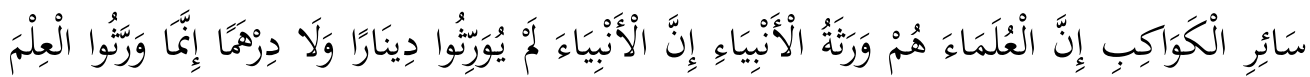

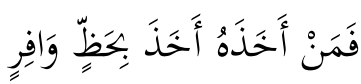

e. Hadis yang di takhrij oleh Imam At Tirmidzit ${ }^{46}$

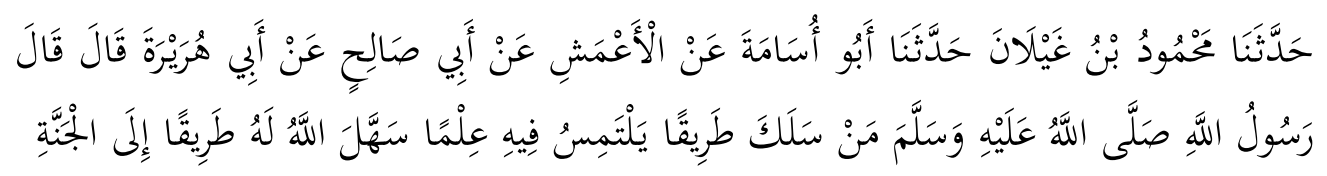

\section{Bagan Seluruh Jalur Sanad Multi Sahabat}

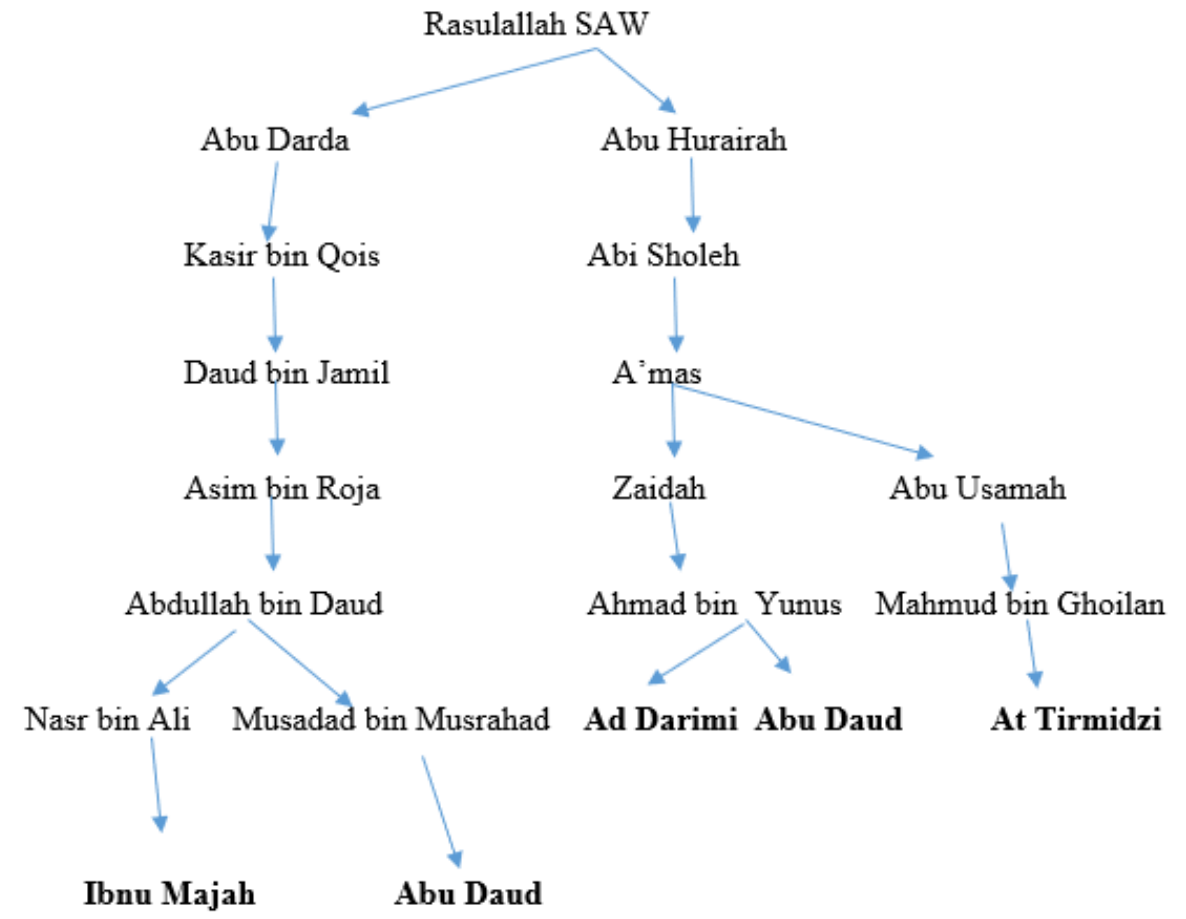

\section{Analisis}

Hadis pentingnya ilmu pengetahuan riwayat Abu Darda' tersebut, setelah diteliti (dilakukan penelitia dan dianalisis) secara parsial (satu jalur sanad), maka diperoleh hasil bahwa hadis tersebut berkualitas sabih lid₹aatih.

${ }^{46}$ Muhammad bin Isa, Sunan At Tirmidzi, Juz. 9, hal. 243, No. 2570, CD Shoftware Maktabah Syamilah, Isdar al Thani 
Kemudian selanjutnya, hadis tersebut diteliti (dilakukan penelitian) secara simultan (multi sahabat), ternyata pentingnya ilmu pengetahuan tersebut juga diriwayatkan oleh sahabat lain, yaitu: sahabat Abu Hurairah. Jadi hadis pentingnya ilmu pengetahuan tersebut diriwayatkan oleh 2 orang sahabat, yaitu: sahabat Abu Darda' dan Abu Hurairah. Dengan demikian secara kuantitas pentingnya ilmu pengetahuan tersebut, meningkat menjadi berderajat masybur (abad masybur), karena diriwayatkan oleh 2 orang sahabat.

Hadis pentingnya ilmu pengetahuan tersebut secara kualitas, berkualitas shabih. Karena memiliki 2 hadis shabid, kualitas hadis tersebut seharusnya meningkat. Tetapi karena hadis tersebut sudah berkualitas sahih, maka tidak bisa meningkat lagi, karena tidak ada lagi tingkatan yang lebih tinggi dari kualitas shabih.

\section{Kesimpulan Analisa Simultan}

Dalam penelitian melalui satu jalur sanad (parsial) menghasilkan kesimpulan bahwa hadis yang diriwayatkan oleh Abu Darda' dab ditakhrij oleh Abu Dawud tersebut, adalah memiliki kualitas shabih lidzatih.

Setelah di lakukan penelitian terhadap tawabi'nya, di dapatkan bahwa hadis tersebut mempunyai 4 hadis tabi'. Tetapi karena kulitas hadis tersebut sudah berada pada derajat shahih, maka keberadaan dari 4 hadis tabi'nya tidak memiliki pengaruh dan tidak mampu untuk meningkatkan kualitasnya.

Penelitian dalam hadis syawabid-nya, ternyata hadis ini tidak memiliki 2 hadis Syabid, artinya hadis ini diriwayatkan oleh dua orang sahabat, yakni Abu Darda' dan Abu Hurairah. Dengan demikian secara kuantitas hadis pentingnya menuntut ilmu tersebut, meningkat menjadi berderajat masybur (ahad mashhur), karena diriwayatkan oleh 2 orang sahabat, tetapi kualitas tetap berkualitas shabih. Karena hadis tersebut memiliki 2 hadis shabid, derajat atau kualitas hadis tersebut seharusnya meningkat. Tetapi karena hadis tersebut sudah memiliki kualitas sabih, maka tidak bisa meningkat lagi, karena sudah tidak ada lagi tingkatan yang lebih tinggi dari kualitas shabih.

\section{Kesimpulan}

Dari serangkaian pembahasan penelitian sanad hadis secara simultan, maka ada beberapa hal yang dapat disimpulkan sebagai berikut: Hasil penelitian hadis secara parsial, menyimpulkan bahwa hadis riwayat Abu Darda' yang ditakbrij oleh Abu Dawud terkait keutamaan penuntut ilmu adalah berkualitas sabih lidzaatih. Penelitian terhadap 4 tawabi'nya, menemukan bahwa hadis tersebut mempunyai hadis tabi'. Tetapi karena kualitas hadis tersebut sudah berkualitas sabih, keberadaan hadis tawabi'nya tidak bisa meningkatkan kualitasnya. Penelitian terhadap shawahidnya, menemukan bahwa hadis tersebut memiliki shabidnya yaitu lewat jalur Abu Darda dan Abu Hurairah. Dengan demikian berarti hadis tersebut 
derajatnya meningkat menjadi ahad mashbur (sebagian mubaddisthin menyebutnya mashbur saja), tetapi kualitasnya tidak meningkat dan tetap berkualitas shabih. Jadi kesimpulannya adalah bahwa hadis yang diriwayatkan oleh Abu Darda' dan di takhrij oleh Abu Dawud memiliki derajat shahib masybur (shabih secara kualitas dan mashbur secara kuantitas).

\section{Bibliografi}

Karim Amrullah, Abdul, Keutamaan Ilmu dan Adab Dalam Perspektif Islam, At-Ta'lim Jurnal Kajian Pendidikan Agama Islam, Vol 2 Edisi 1, http://www.ejournal.annadwah.ac.id/index.php/Attalim/article/view/1 33, 2020

Abdullah bin Abdirrahman Abu Muhammad Ad Darimi, Sunan Ad Darimi, Shoftware Maktabah Syamilah, Isdar al Thani

Abu Abdillah Muhammad ibn Yazid, Sunan Ibnu Majah, CD Shoftware Maktabah Syamilah, Isdar al Thani

Abu Dawud Sulaiman bin Al Ash'ath, Sunan Abu Dawnd, CD Shoftware Maktabah Syamilah, Isdar al Thani

Setiawan, Agus, Reorientasi Keutamaan Ilmu dalam Pendidikan Perspektif Al Ghazali pada Kitab Ihya Ulumuddin, Jurnal Al Qalam, Vol. 12 No.1https://jurnal.stiqamuntai.ac.id/index.php/alqalam/article/view/18 /18 tahun 2018.

Fauzi, Ahmad dan Alfiah, Urgensi dan Keutamaan Kedudukan Ilmu yang Bermanfaat sebagai Asset Akbirat, Journal of Education and Teaching, Vol. 2 No. 2, http://ejournal.uin-suska.ac.id/index.php/JETE 2021

Al Mizzi, Tabdribul Kamal, CD Shoftware Maktabah Syamilah, Isdar al Thani

Damanhuri, Hadis-Hadis Al Fitrah dalam Penelitian Simultan, (Sidoarjo: Dwiputra Pustaka Jaya, 2016).

Ibnu hajar, Tabdbibu Tabdbib, CD Shoftware Maktabah Syamilah, Isdar al Thani

Ibnu Rajab Al Hanbali, Jami' Al Ulum wa Al Hikam, (Beirut: Muassasah ArRisalah, $1432 \mathrm{H}$.)

Ismail, Syuhudi, 1994, Pengantar Ilmu Hadis, (Bandung: Angkasa,),

Klaus Krippendorff, Analisis Isi, Pengantar, Teori dan Metodologi. (Jakarta: Rajawali Press, 1991)

Mahmud Tahhan, tt, Taysir Mustalah al-Hadith, (Kuwait: Maktabah al Maa'rif li alnasr wa al-tawzii),CD Shoftware Maktabah Shamilah, Isdar al-Thani. 
Mera Fidiana, "Pendidikan Islam Menurut Az-Zarnuji (Studi Analisis Konsep Ilmu dan Keutamannya dalam Kitab Ta'lim Muta'alim)", Skripsi, Pendidikan Agama Islam, IAIN Metro, 2018. https://repository.metrouniv.ac.id/id/eprint/2382/

Muhammad bin Hibban, Shabih Ibnu Hiban, CD Shoftware Maktabah Syamilah, Isdar al Thani

Muzakkir, "Keutamaan belajar dan mengajarkan Al Qur'an (Metode Maudhu'I dalam perspektif Hadis)". Jumal Lentera Pendidikan, 18(1), 2015, http://journal.uinalauddin.ac.id/index.php/lentera_pendidikan/article/v iew/684/672

Shofiyudin Ahmad bin Abdillah, Kbulasob Tabdhibu Tabdhib Al Kamal fi Asma' Ar Rijal, CD Shoftware Maktabah Syamilah, Isdar al Thani

Syamsudin Abu Abdillah, Mizanul I'tidal, CD Shoftware Maktabah Syamilah, Isdar al Thani 